\title{
Fear follows form: A study of the relationship between neighborhood type, income and fear of crime at train stations
}

\author{
Sofie Kirt Strandbygaard \\ Danish Transport, Construction and \\ Housing Authority and Technical University \\ of Denmark \\ sofieks@byg.dtu.dk
}

\section{Alan Keith Spence Jones \\ Danish Transport, Construction and Housing Authority \\ alkj@tbst.dk}

Lotte M. B. Jensen

Technical University of Denmark

lbj@byg.dtu.dk

\author{
Otto Anker Nielsen \\ Technical University of Denmark \\ oani@dtu.dk \\ Bo Grönlund \\ The Royal Danish Academy of Fine Arts \\ bgron@kadk.dk
}

\begin{abstract}
In pursuing fear-reduction strategies in public transport, the total experience of accessing rail stations should be taken into account. This article correlates passengers' fear of crime at train stations with neighborhood types and income data within the pedestrian catchment area. The research is based on urban form and income around 84 $S$-train stations in the Copenhagen metropolitan area and nine years of passenger surveys on fear of crime at these stations. The study reveals a significant positive correlation between low income and fear of crime; the lower the income in an urban area, the more unsafe passengers feel at the station. However, when controlling for the relationship between income, safety and neighborhood type, stations in neighborhoods with urban form associated with low incomes have the lowest ratings of safety. The research indicates that train passengers' sense of security is connected to neighborhood type and the city's planning characteristics. This is an important finding for urban designers and planners working on the integration of public transport and station design in urban areas.
\end{abstract}

\section{$1 \quad$ Introduction}

Recent passenger surveys in Copenhagen and previous international research shows that passengers' fear of crime in public transport is higher than in other public spaces and much higher

\section{Article history:}

Received: October 2, 2019

Received in revised form: March

17,2020

Accepted: August 2, 2020

Available online: November 18, 2020

Copyright 2020 Sofie Kirt Strandbygaard, Otto Anker Nielsen, Alan Keith Spence Jones, Bo Grönlund \& Lotte M. B. Jensen http://dx.doi.org/10.5198/jtlu.2020.1675

ISSN: 1938-7849 | Licensed under the Creative Commons Attribution - Noncommercial License 4.0 The Journal of Transport and Land Use is the official journal of the World Society for Transport and Land Use (WSTLUR) and is published and sponsored by the University of Minnesota Center for Transportation Studies. 
than the actual risk of becoming a victim of crime (Ceccato, 2013; Cozens \& Van der Linde, 2015; CrimeConcern 2004; Københavns Kommune, 2019; Warr, 2000). Research has demonstrated how passengers' fear of crime at railway stations and crime patterns can be linked to the characteristics of the urban environments that surround the stations (Ceccato, 2013; Loukaitou-Sideris, 2005; Uittenbogaard, 2014). This influences travel choices, such as walking to the station and choosing the means of transportation and the time of travel (Liggett, Loukaitou-Sideris, \& Iseki, 2001;Loukaitou-Sideris, Liggett, \& Iseki, 2002). When train stations in general are perceived as unsafe urban locations, it presents a significant societal problem since a cornerstone of environmentally and socially sustainable societies is the ability of citizens to move freely within and across the city by public transport (Ceccato, 2013).

This article explores how passengers' experience of fear of crime at train stations relates to the surrounding urban area. Previous research on this theme has established a relationship between station neighborhood typologies and passengers' fear of crime (Strandbygaard et al., forthcoming). However, socioeconomic factors are influential in determining an individual's experience of fear of crime (Doran \& Burgess, 2012; Farrall, Bannister, Ditton, \& Gilchrist, 2007). Therefore, this article provides an analysis of the relationship between income, urban form and fear of crime in order to contribute to the body of knowledge in the field and to analyze their separate influence on fear of crime at $S$-train stations.

The research is based on $84 \mathrm{~S}$-train stations in the Copenhagen metropolitan area and their passenger catchment areas (PCAs) or in Danish, "Det stationsnære område" (the urban area near the station) (Hartoft-Nielsen, 1997), as well as a walking distance of $800 \mathrm{~m}$ or a half-mile radius around the station (Cervero, Guerra, \& Al, 2017). This research combines typo-morphological ${ }^{1}$ analysis of station neighborhoods within each station with income data for the PCAs and the passenger surveys of fear of crime.

The data on passengers' fear of crime come from nine years of quarterly surveys at S-train stations: 125,449 passenger surveys from the DSB (Danish State Railways) and Passenger Pulse, an independent transport survey organization. The survey is based on the passenger's most frequently used departure station. Approximately $80 \%$ of all S-train passengers either walk or cycle to the departure station within the Copenhagen area and thus experience the surrounding urban area (Trafikstyrelsen, 2009). Furthermore, the S-train stations are open unmanned platforms with visual contact with their surroundings and a part of the free urban flow. This integral layout makes it relevant to turn the analysis of fear of crime at these stations in the direction of the surrounding urban area.

The aim of this research is to analyze the connection between the urban layout and the experience of train stations, and thus contribute to knowledge about passengers' experience of train stations. Data on this relationship can support decision-makers in the transport industry in creating better stations and transit areas by recognizing that urban parameters influence passengers' experiences of train stations. The typological approach is used in research on traffic planning to estimate circulation and travel flows, place characteristics and accessibility (Stojanovski, 2018). This article supports this knowledge by addressing fear of crime within this methodological context.

The study consists of a string of analyses. The first one defines the station neighborhood types and the second compares them to the passenger surveys on fear of crime at stations. The third analysis defines the relationship between income and station neighborhood types, and the last is a correlation between fear of crime at the station, station neighborhood types, and income.

The article is organized as follows. Section 2 outlines the theoretical background and describes the social and environmental factors that influence fear of crime, followed by examples of research on urban typologies and socioeconomic factors. Section 3 presents the case study and the preliminary work on the typologies. Section 4 describes the data and methodology used. Section 5 presents the results and discusses the relationships between income levels, fear of crime and neighborhood types. Section 6 concludes on the research findings and provides recommendations for future research.

${ }^{1}$ That is, grouping urban patterns into typologies and classifying them. 


\section{Theory and literature review}

\subsection{Fear of crime}

"Fear of crime" is defined as "the fear of becoming victim of crime; the perception of the risk of becoming a victim of crime; feelings of safety; perceptions and responses to the threat of crime and criminal victimization; worry, concern and anxiety about victimization and crime," (Vanderveen, 2006, p.18). "Fear of crime" is a broad term that covers the feelings of both anticipated fear and actual fear (Garofalo, 1981), or formless fear and concrete fear (Ferraro \& Grange, 1987), where the formless or anticipated fear does not relate to any particular crime. Fear of crime is not necessarily related directly to symbols of crime (such as broken windows or syringes left on the ground), but may also be linked to feelings of anxiety or low perceptions of safety due to the nature of the local urban layout, such as dark or deserted areas (Doran \& Burgess, 2012; Painter, 1996).

The fear of crime may reflect a state of anxiety caused by the impact of different social factors, thus, low socioeconomic status is connected with fear of crime. Several theories and hypotheses posit this relationship: for example, demographic theories examine whether individuals' fear of crime is associated with previous experiences of crime or feelings of vulnerability (Doran \& Burgess, 2012; Farrall et al., 2007). The "victimization hypothesis" posits a positive relationship between direct experience of victimization and fear of crime (Doran \& Burgess 2012; Skogan \& Maxfield, 1981). The "indirect victimization hypothesis" recognizes that "non-victims" also experience fear of crime under the influence of what they hear of others' encounters with crime. This also relates to the exposure to crime through social networks, the media and to interpersonal communication in social media (Doran \& Burgess, 2012; Hanson, Smith, Kilpatrick, \& Freedy, 2000; Taylor \& Hale, 1986). The "vulnerabilities hypothesis" assumes that different sociodemographic groups have different experiences of fear of crime. This theory addresses exposure to risk, loss of control and the seriousness of the consequences of this for your life the more vulnerable you are, the greater the consequences (Killias, 1990; Warr, 2000).

Skogan and Maxfield (1981) separate social vulnerability from physical vulnerability. Physical vulnerability refers to one's ability to resist an attack and recover from it. Social vulnerabilities reflect the individual's position in society and include income, residential status, educational level, ethnic background, whether one lives alone and previous experiences of victimization. Social theories relate to the social environment surrounding the individual and focus on the influence of different social factors in the individual's environment: thus Shaw and McKay's (1942) "social disorganization hypothesis" linked delinquency rates to community characteristics. This theory has since been extended to cover the fear of crime as well (Taylor \& Covington, 1993).

A number of surveys investigating the relationship between socioeconomically deprived residential areas and fear of crime have been conducted in the Nordic countries, confirming the research outlined above. The annual report of the Danish National Police, Tryghedsmålinger 2018 (Rigspolitiet, 2018a; 2018b), shows that people in so-called SUB areas (especially vulnerable urban areas) have higher levels of fear of crime than in other parts of Denmark. A report by the Swedish National Council for Crime Prevention indicates that women and men are more exposed to violence in socioeconomically vulnerable areas, and that women in these areas are more afraid than women in other urban areas (BRA, 2018, p. 23). These surveys underline the fact that low-income areas have higher levels of fear of crime. 


\subsection{Environmental factors: The built environment and fear of crime}

Environmental factors, especially the relationship between the built environment and fear of crime, have become an area of increasing interest within criminology (Ceccato, 2015; Doran \& Burgess, 2012; Ryan et al., 2010). Based on Crime Prevention Through Environmental Design (Jeffery, 1971; Newman, 1972) and theories of urban form, the following five parameters are suggested in order to present an overview of the body of knowledge connecting the built environment with fear of crime. The characteristics are embedded in the neighborhood typologies (Strandbygaard et al., forthcoming).

First, natural surveillance, or "eyes on the street" (Jacobs, 1961), monitoring residents and nonresidents alike, can support positive normative behavior through social control and thus lower the fear of crime (Jeffery, 1971). This is supported by mixed land use with activities in the street day and night. The ability of residents to see each other through windows, entrances, balconies and so forth supports the surveillance (Desyllas, Connoly, \& Hebbert, 2003; Felson, Clarke, \& Webb, 1998). Second, visual guidelines and clear demarcations between public and private spaces encourage residents to assume ownership and control of their own areas. This encourages normative behavior and thus enhances feelings of safety (Jacobs, 1961; Newman, 1972; AGIS, 2007) Residential status has an influence here, as areas of home ownership exhibit higher levels of territoriality and social control than areas of rented accommodation (Greenberg, Rohe, \& Williams, 1982).

Third, spatial qualities and human scale are also significant. Out-of-scale areas can be perceived as unsafe, possibly leaving residents feeling exposed and under hostile surveillance (Gehl, 2010; Jacobs, 1993; Knöll, Neuheuser, Cleff, \& Rudolph-Cleff, 2018). Enclosure defines spatial qualities, creating a visual overview related to feelings of safety. The sense of enclosure is eroded if the streetscape is discontinuous, with vacant lots, parking lots, lawns or buildings set back from the road (Cullen, 1961). An enclosure ratio ceases to be comfortable somewhere around 1:4, while beyond 1:6 the feeling of being enclosed disappears (Harvey, Aultman-Hall, Hurley, \& Troy, 2015; Spooner, 2007). Complexity, beauty and robustness are key visual and sensory qualities linked to senses of territoriality and ownership (Gehl, 2010; Jacobs, 1993). Fourth, maintenance signals community cohesion, reveals the norms followed by local residents and indicates whether anyone will intervene in the event of a crime (Goffman, 1972; Wilson \& Kelling, 1982). Fifth, light has an overwhelming effect on perceptions of safety, as without it, it is not possible to see what might be lurking in the darkness (Peña-García, Hurtado, Aguilar-Luzón, 2015).

All of these parameters influence residents' perceptions of safety in the built environment and are embedded in the different types of station neighborhood. Neither maintenance nor lighting is incorporated into the present analysis, as they both require a detailed, micro-level investigation of urban areas that differs from the typo-morphological analysis of the urban fabric surrounding stations that is addressed in the present research.

\subsection{The relationship between neighborhood and socioeconomic structure}

Urban typo-morphology classifies urban space into types based on detailed classification by the types of the elements that shape its urban form: streets, plots and buildings, and to follow variations and mutation over time (Moudon, 1992; 1994). The interest in urban typologies and socioeconomic structures is rooted in urban sociology and the work of the Chicago School, for which the city was conceived as a mosaic of urban areas containing different socioeconomic residential groups (Park \& Burgess, 1925). Swedish urban typo-morphologists argue that neighborhood type encompasses not only density variables in the form of residential densities (Rådberg \& Friberg, 1996), but also social structure and devel- 
opment tendencies (Engström, 1988; Stojanovski, 2018). Neighborhood type is an aggregate variable that incorporates building types, their use and history, the spatial qualities of public spaces and street networks. It is argued that this mosaic of neighborhood types is correlated with the socioeconomic status of its residents (Engström, 1988). Following up on research into Swedish typologies, in 2011 the Swedish company Spacescape made a graphic visualization of how neighborhood types in Stockholm are related to socioeconomic status and certain urban qualities (parks, playgrounds, libraries, public transportation, street crossings, etc.) (Bremberg, Slättman, \& Alarcón, 2015). Figure 1 shows that suburbs dating from 1960-1990, indicated by the purple dots, have fewer urban qualities and a lower socioeconomic index than the detached housing estates indicated by the green dots or inner-city areas indicated by the orange dots at the top of the $Y$ axis.

Others have sought to establish a systematic quantifiable method of analyzing urban form and determining the morphological parameters that support the neighborhoods' gentrification process (Venerandi, Zanella, Romice, Dibble, \& Porta, 2017). Their findings show that "sanctuary areas" of fine-grained, perimeter block-based urban form with low traffic levels characterize gentrified neighborhoods. These areas share many of the same characteristics as Jacobs and Appleyard's (1987) "good" urban districts consisting of well-managed environments that are relatively devoid of nuisance.

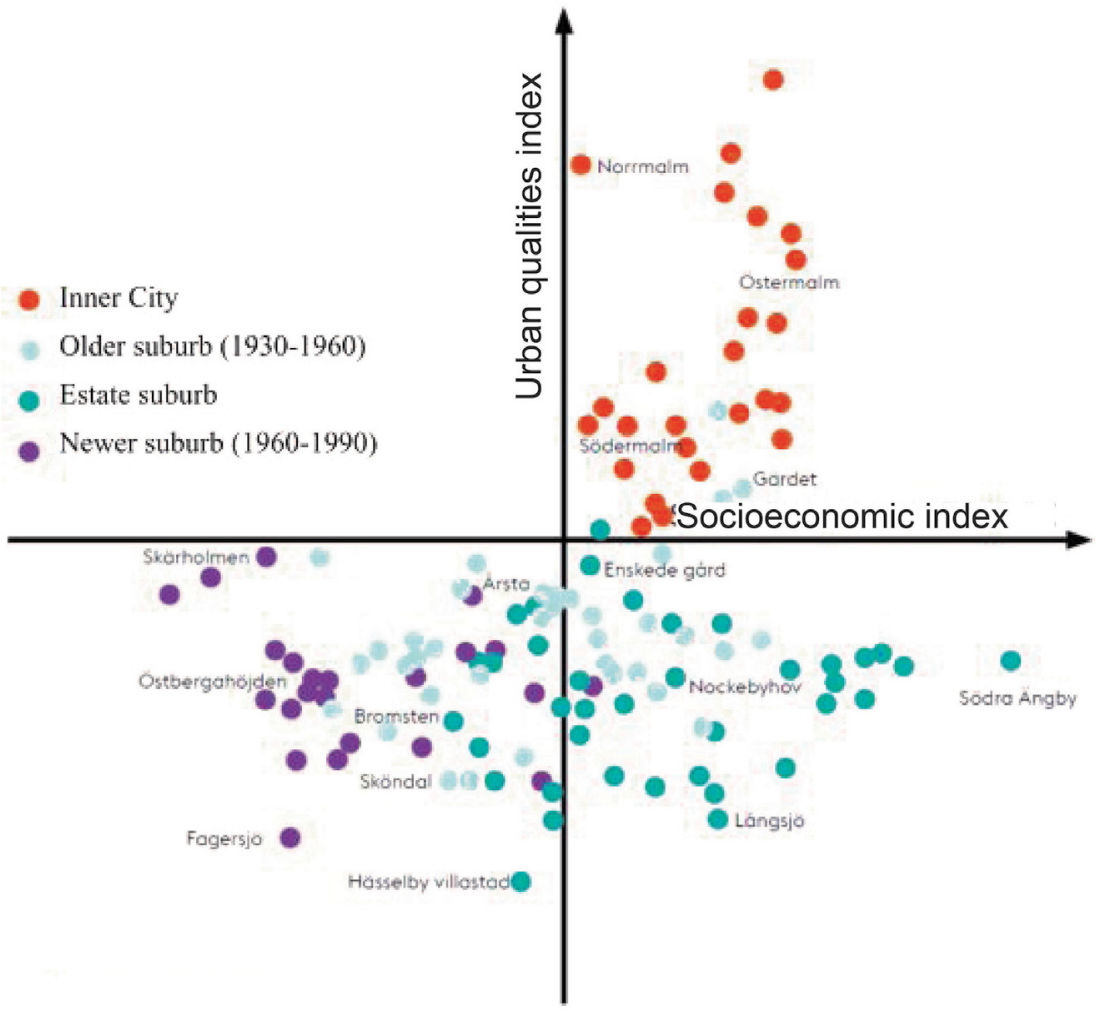

Figure 1. Scatterplot of urban types placed in their socioeconomic contexts and urban qualities in the report Skillnadernas Stockholm (Stockholm's differences). The illustration is translated into English (Bremberg et al., 2015, p.60) 


\section{The case study and background analysis}

This section presents the case study, the definition of neighborhood typologies and their location in the Copenhagen metropolitan area in order to provide the reader with a historical and geographical context.

\subsection{The case study}

The research is based on case studies of S-train stations in the Copenhagen metropolitan area. The Strain system is the urban rail system in the Finger Plan, a regional infrastructural plan for the post-war development of Copenhagen from 1947 (Egnsplankontoret, 1947; Knowles, 2012) that largely guided development in the region thereafter. The Finger Plan resembles a hand placed over a map of Greater Copenhagen (Figure 2): the S-train system runs along the five fingers based on existing train lines and main roads. The system has seven lines, $170 \mathrm{~km}$ of track and 84 stations. It covers the entire metropolitan area and therefore includes all types of urban planning and socioeconomic structures.

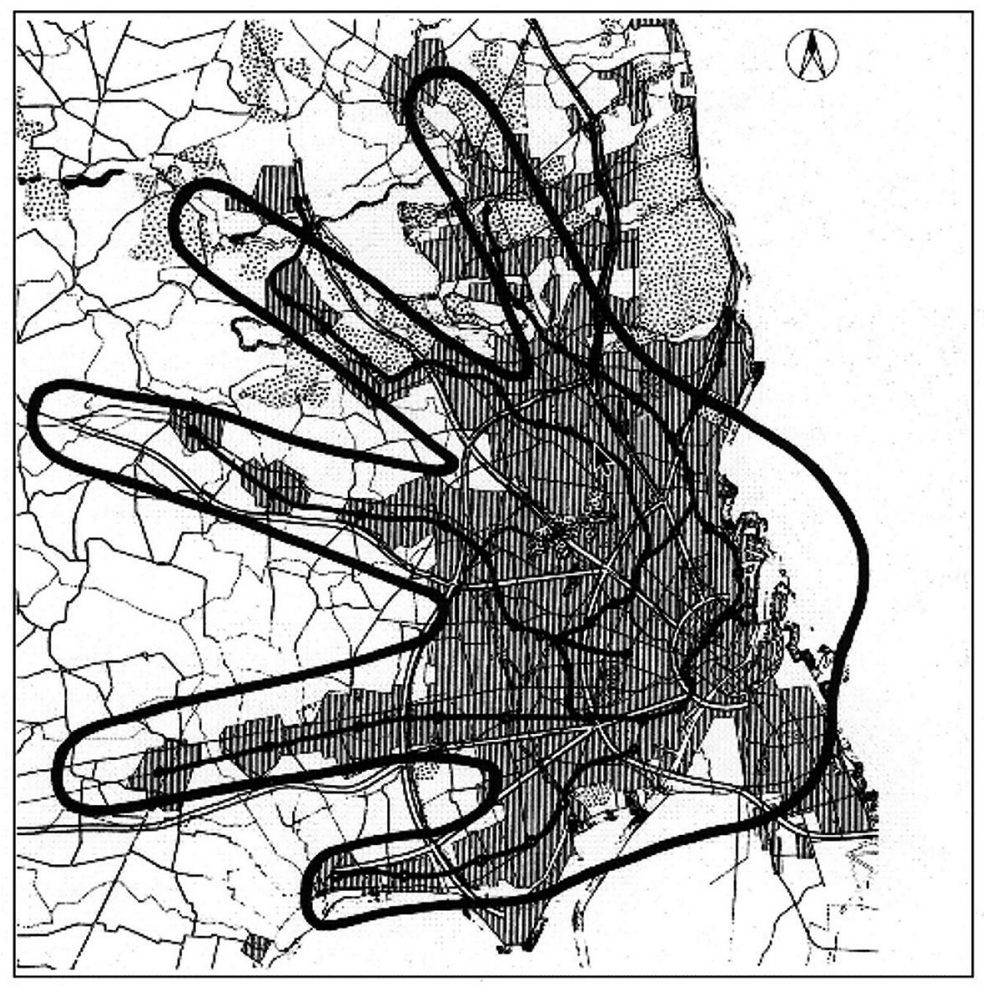

Figure 2. The finger plan (Byplanlaboratorium, 1993, front page)

\subsection{Classifying and mapping station neighborhood types}

In a previous study, station neighborhood types were classified and mapped on the basis of their building types, their use and history, the spatial qualities of public space related to fear of crime, and the street network (Strandbygaard et al., forthcoming). The three main neighborhood types are: A, Dense Urban Area; B, Coherent Suburb; and C, Fragmented Suburb (Figure 3). The neighborhood types are outlined in ArcMap by displaying only the buildings' footprints or figure-ground plans in order to reveal the de- 
gree of urban compactness, that is, the distances between volumes and their sizes, how they define streets and urban spaces and the degree of enclosure. The street network, the plot and the buildings' use and time of construction also determine the building typologies. Public buildings or monumental elements belong to the typology within which they were built and planned (year and building style). As the focus of this study is the station, the public space surrounding the station entrance, defined by a degree of visual proximity of approximately a hundred meters, identifies the neighborhood type. If the main area of the $800 \mathrm{~m}$ walking radius belongs to the same type, it becomes a main type. The neighborhood types also have subcategories for cases in which the urban fabric can be defined mainly as type A, B or C, but also contains significant elements of one of the other patterns. Thus, if the area surrounding the station is classed as A and the minor element is $\mathrm{C}$, a small letter " $\mathrm{c}$ " is used to denote the latter, resulting in a subcategory marked "Ac." In these cases there must either be a substantial number of building elements from another typology or they need to be sufficiently central to the station entrance to exert an influence over the urban area and thus denote the neighborhood type.
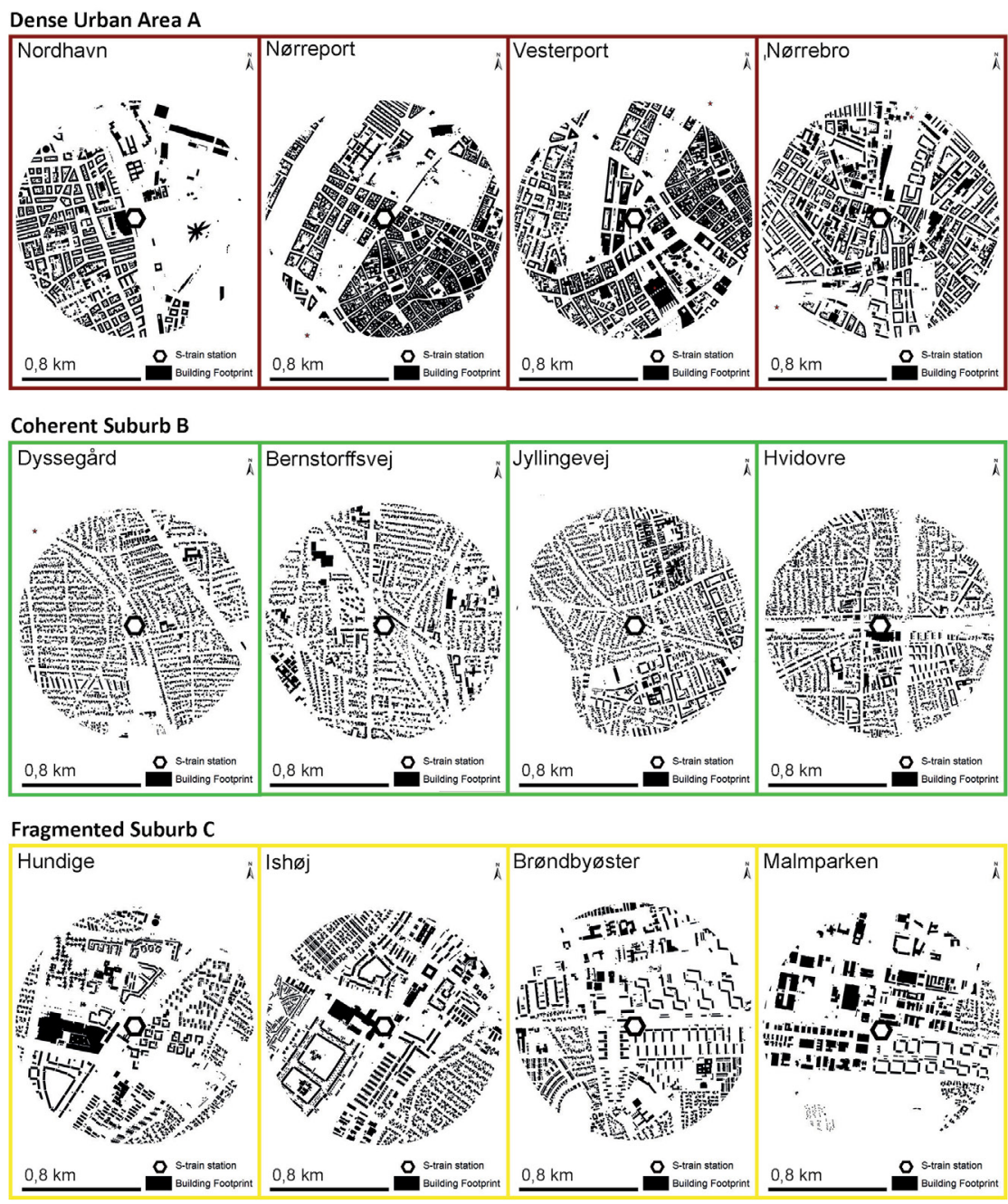

Figure 3. Examples of the three main station neighborhood types. (Strandbygaard et al., forthcoming). 
Type A, the Dense Urban Area, mostly consists of five-story courtyard building blocks with closed internal courtyards and streets with an enclosure ratio as high as 1:2, the street being ten meters wide and the building twenty meters high. In central Copenhagen this type dates back to the seventeenth century, while the urban areas to the south, east and north-east of the city center were built for the working classes in the nineteenth and twentieth centuries. Type A has windows towards the street, cafés or shops on the ground floor. There is a high degree of building compactness, and in many areas a high level of urban activity and natural surveillance. This urban typology has a high level of urban activity and natural surveillance, features that relate to the experience of safety.

Type B, the Coherent Suburb, has a considerably lower degree of compactness than the Dense Urban Area. Most of the building mass consists of one- to two-story detached single-family housing. The building footprints are small and are spread out in a homogeneous pattern, with elements juxtaposed in a consistent manner. Most of these areas close to Copenhagen were built between 1900 and 1950, when the age of the car had not yet arrived and the building industry had not yet become industrialized. This building typology has front gardens with trees and hedges along the sidewalk creating a clear demarcation between private and public spaces. The scale is human, and there are high levels of territoriality and visual diversity, as well as clearly defined spaces. This points towards an urban typology associated with perceptions of safety, despite the relatively low level of urban activity.

Type C, the Fragmented Suburb, differs from the other types in having larger areas of open space in between the building mass. The spatial hierarchy is diverse, the organization of the building footprints open. This neighborhood type stems from post-war development continuing up until the present day and consists, among other building typologies, of apartment blocks and social housing projects with common green areas. The scale of the infrastructure for cars has set the standard for these urban areas (Nielsen, 2008). Large-scale parking requirements, combined with planning ideals about single-use areas, open green spaces and segregated traffic, have generated low building densities, a low feeling of enclosure and low levels of social control, streetscape features associated with low perceptions of safety.

\subsection{Spatial distribution of neighborhood types in the Copenhagen metropolitan area}

The map of neighborhood types according to the definitions in section 3.2 and their location in the metropolitan area (Figure 4) shows that type A, the Dense Urban Area, is concentrated in the center of Copenhagen, the oldest and densest part of the capital. Type B, the Coherent Suburb, is the next layer of building typology around the central urban area, extending to the north. Before the 1950s, before private cars shaped urban planning, residents who could afford their own houses and gardens moved here and into the hilly and popular northern area close to the beaches and forest. In the 1950s, the western and southern parts of Greater Copenhagen had large areas of undeveloped land, and this led to an extensive distribution of both public housing and industry as part of the modernist-inspired post-war expansion of Copenhagen. Thus, type C, the Fragmented Suburb, is the most characteristic of these areas. This map provides a geographical overview of the initial results. 


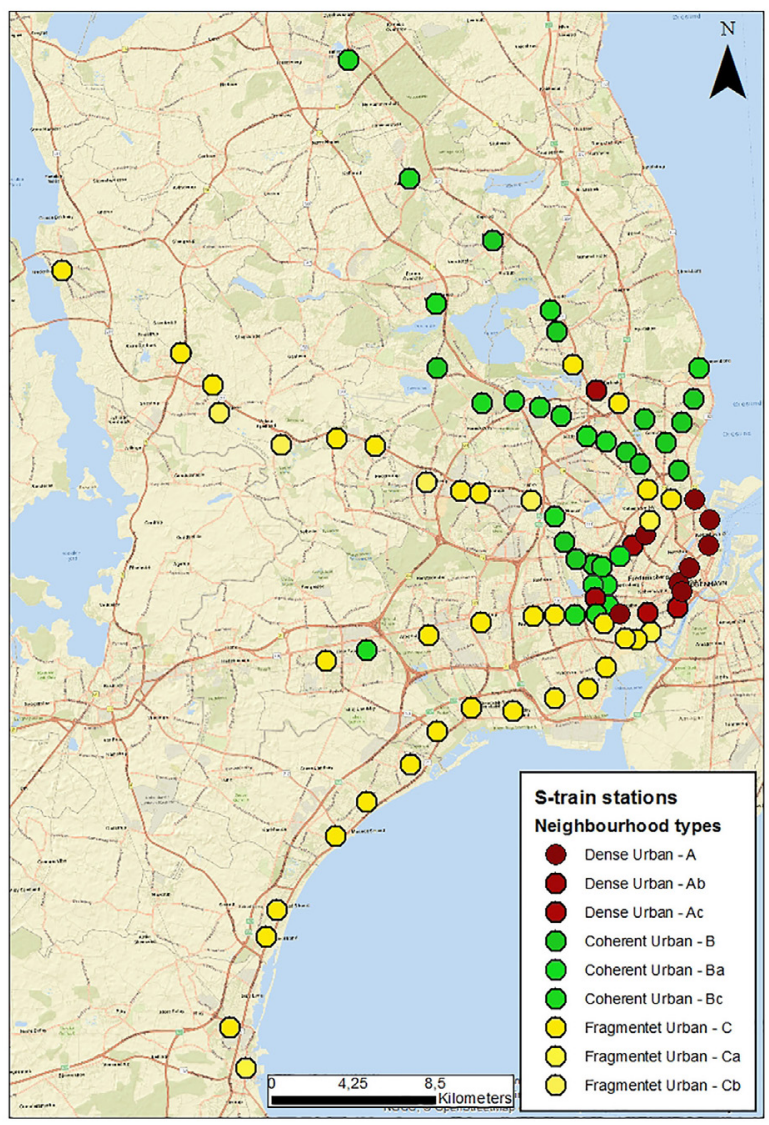

Figure 4. Neighborhood types in the Copenhagen metropolitan area (Strandbygaard et al., forthcoming)

\section{$4 \quad$ Methodology}

The following briefly describes the passenger survey used to measure fear of crime at stations, the method for estimating and visualizing the neighborhood typologies' level of fear of crime, and finally it describes the income data and how they are connected to neighborhood typologies.

\subsection{The passenger survey: Fear of crime at S-train stations}

The data on experiences of safety at train stations used here come from nine years of quarterly passenger surveys. The passenger survey dataset has two sources: DSB conducted 87,545 interviews in 20092015, while Passenger Pulse (Forbrugerrådet Tænk, 2019) conducted 37,904 interviews in 2016-2018. The questionnaire used was the same, but the survey was taken over by an independent organization to ensure that the data would be made publicly available. The survey is handed out every quarter to approximately two thousand representative passengers on S-train platforms between 6 am and $10 \mathrm{pm}$. The questionnaire asks about general satisfaction with public transport, with one question eliciting passengers' perceptions of safety at the station. Passengers are asked to rate their feelings of safety at their most frequently used departure station on a scale from 0 to 10,0 being unsafe and 10 being safe. Both data suppliers concur that a rating of 7-8 is considered a healthy station and that 5-6 is a low rating for a station. 
The passenger survey is based on individual passengers' experiences of fear of crime at their departure stations, but the many years of data, the station layout and the high level of passengers walking and biking to the station also makes it possible to use the survey as an indicator for passengers' experiences of their station neighborhoods.

\subsection{Fear of crime in relation to station neighborhood types}

In order to demonstrate the probability of each neighborhood type being perceived as safe, a probability density graph of safety and station neighborhood types has been drawn up. The passenger survey provides data on mean safety perceptions at each station from January 2009 to September 2018. An estimate of a probability distribution (a kernel density estimate or $\mathrm{KDE}$ ) is made for each of the neighborhood types A, B and C.

\subsection{Income in relation to station neighborhood types}

The relationship between income and neighborhood type is visualized in a probability distribution of income for each of the neighborhood types A, B and C. The income level per capita is used as a key indicator of socioeconomic status. The income data are drawn from Statistics Denmark (Statistics Denmark, 2019) for 2015 and are aggregated for each of the 84 station neighborhoods. The income data from Statistics Denmark for 2015 is displayed in a $100 \mathrm{~m}$ x $100 \mathrm{~m}$ grid income map of station neighborhoods as illustrated in Figure 8. Grids without color have fewer than fifty individuals and are therefore illegal to record in order to protect anonymity.

\section{$5 \quad$ Results}

\subsection{Fear of crime in the different station neighborhood types}

The three curves in Figure 6 show the probability of each neighborhood type being perceived as safe as described in section 2.3. The green curve, Coherent Suburb neighborhood type B, is perceived as the safest, having the highest mean perceptions of safety (7.71). The yellow curve, Fragmented Suburb, type $\mathrm{C}$, has a mean value of 7.35 , being the lowest of the three main types. 


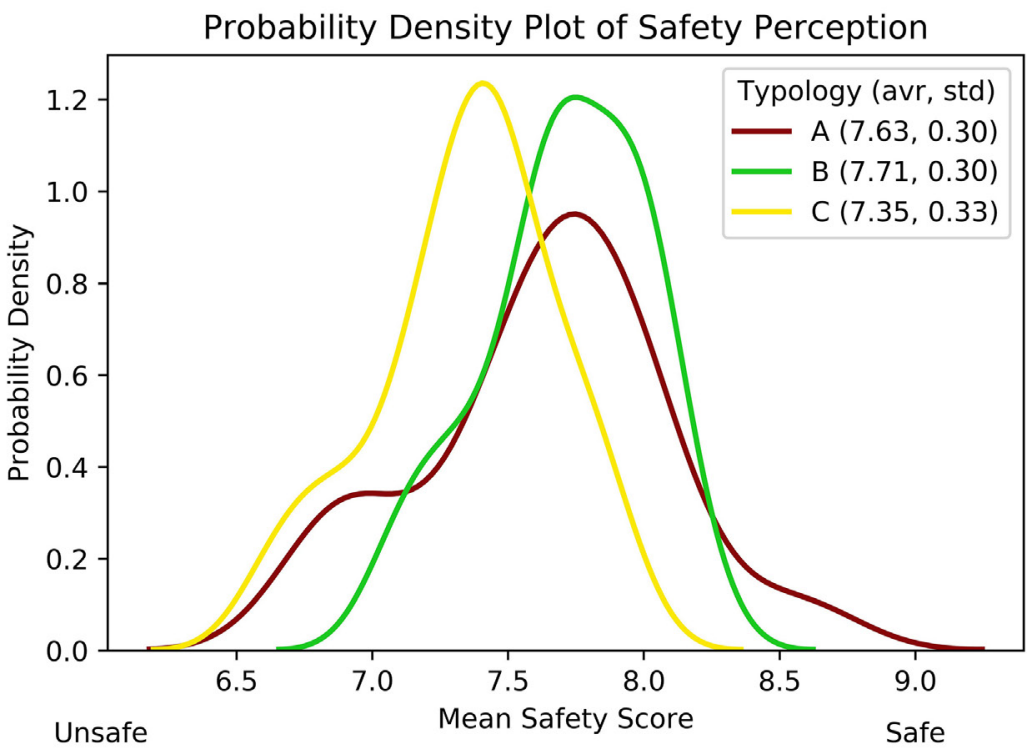

Figure 5. Densities of the three different types being perceived as safe, 2009-2018. (Strandbygaard et al., forthcoming).

\subsection{Income levels of the different station neighborhood types}

Figure 6 shows income levels for the different station neighborhood types. There are clear similarities with the graphs visualizing levels of fear of crime in Figure 5. Figure 6 shows that types A and B have almost the same income levels with wide spans between them, while type $\mathrm{C}$ generally has low-income levels.

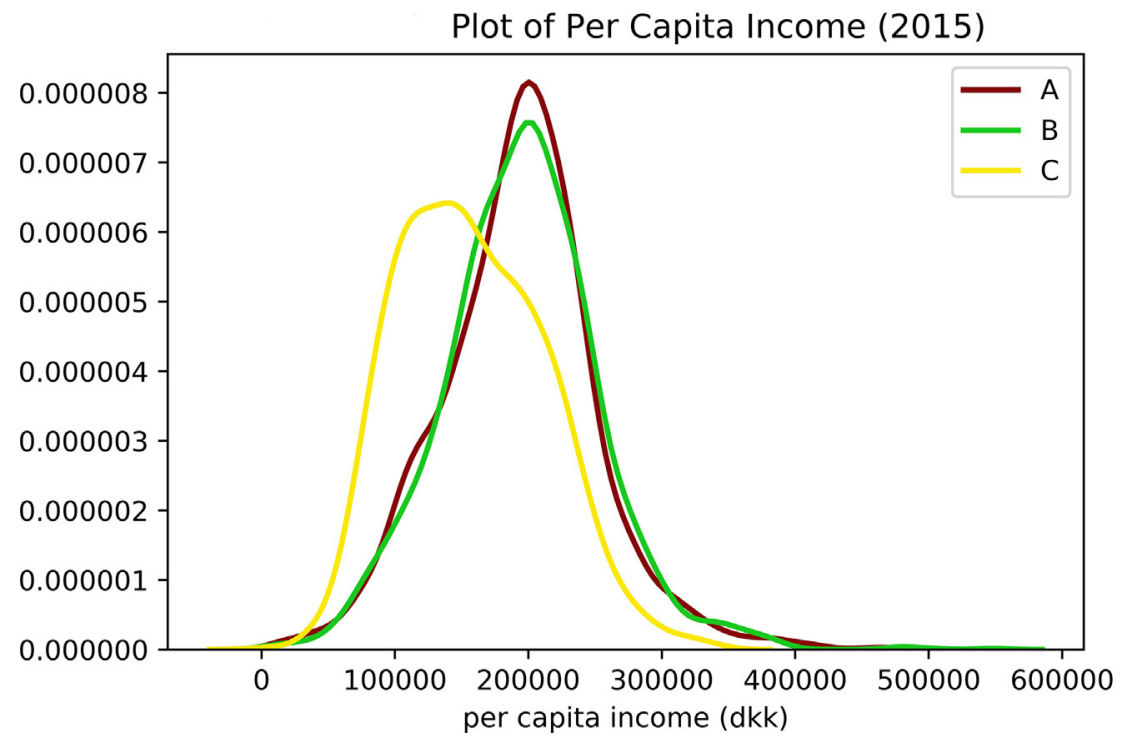

Figure 6. Densities of income from 2015 for each station neighborhood type 


\subsection{Urban form and income patterns}

\section{Income per capita}

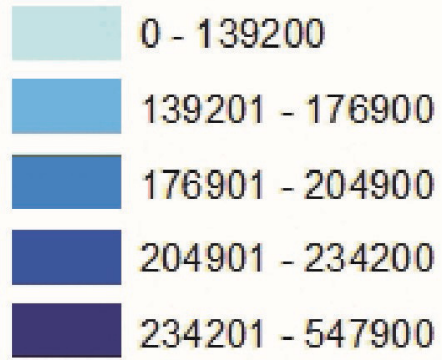

Figure 7. Color indications of income per capita
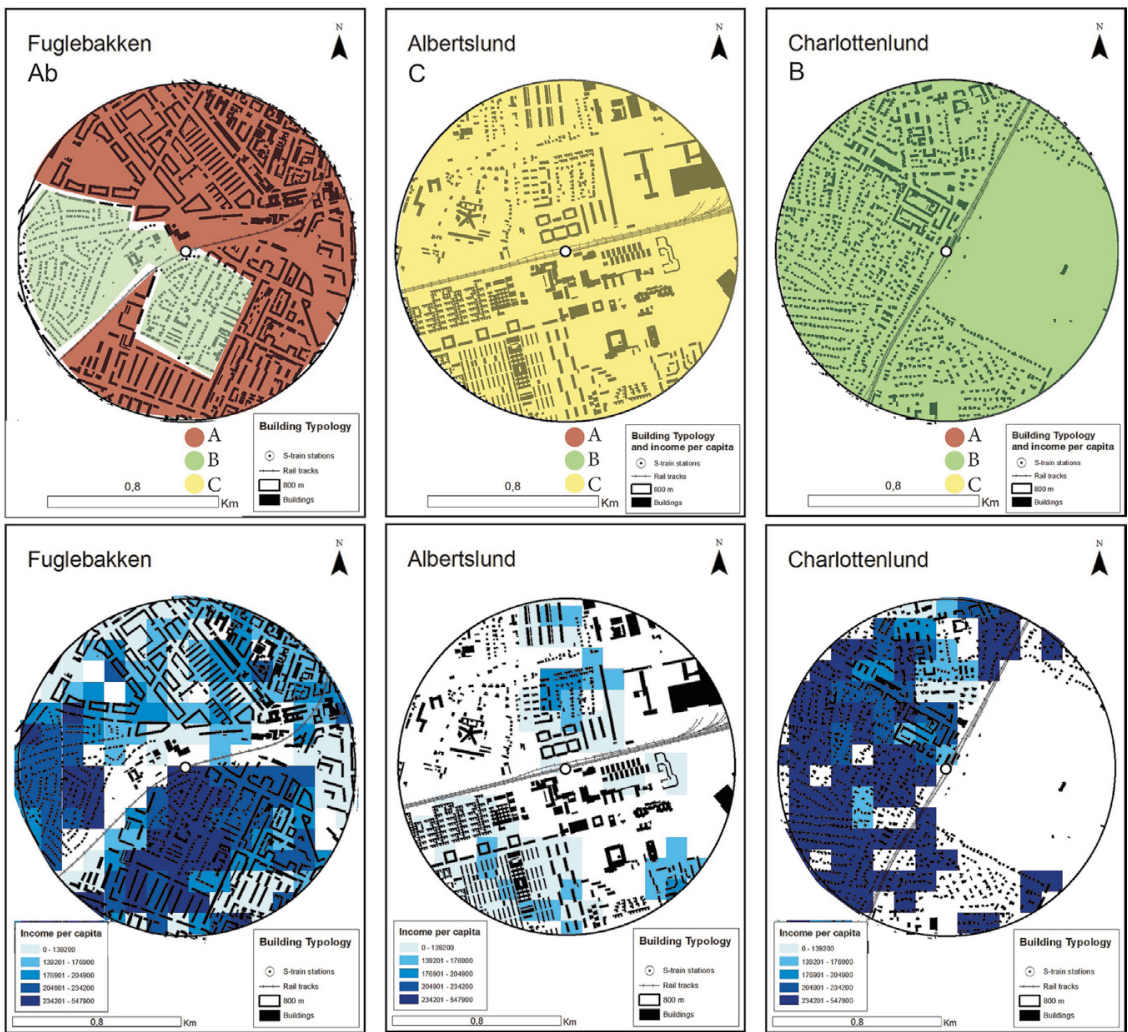

Fuglebakken, type $\mathrm{Ab}$, between to income areas in Copenhagen city.

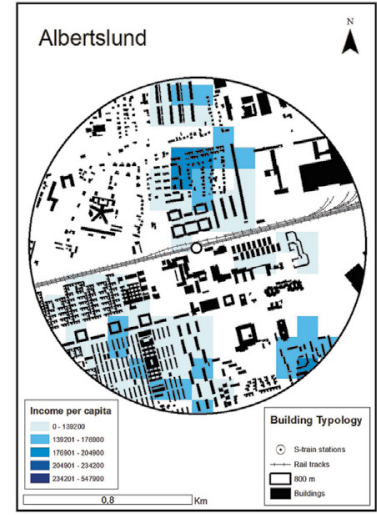

Albertslund, type C, west of Copenhagen

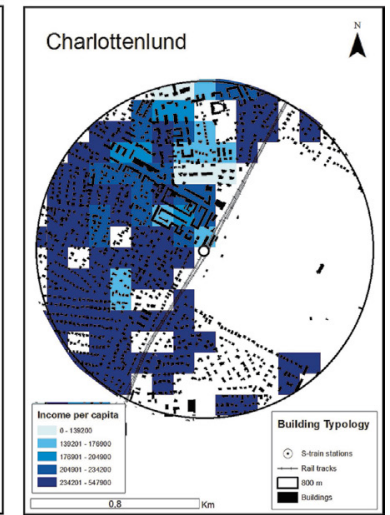

Charlottenlund, type B, north of Copenhagen

Figure 8. Examples of patterns of urban form and income: station neighborhood types: Fuglebakken, type Ab. Albertslund, type $\mathrm{C}$, and Charlottenlund, type B 
The visualization of the relationship between urban form and income in Figure 8 shows how patterns of urban form are directly related to levels of income. The differences are caused by several reasons: private ownership requires a higher income than rental, and single-family houses are more expensive to live in than apartments. Some geographical areas have a high socioeconomic status such as north of Copenhagen, and therefore the colors of high income are an even darker blue. These areas are associated with a pre-war urban form of Coherent Suburb, type B (see Figure 4).

\subsection{Levels of fear of crime at stations in relation to neighborhood incomes}

Figure 9 shows the relationship between fear of crime and levels of income distributed among the three urban types, while Table 1 presents statistics for the three types. As can be seen, there is a tendency towards a lower fear of crime in higher income areas within each type. Types $\mathrm{A}$ and $\mathrm{B}$ have a higher trendline than type $\mathrm{C}$, meaning that, if the population around a station has equal, fixed income levels, then passengers in areas of type $\mathrm{C}$ feel less safe than passengers in type $\mathrm{A}$ or $\mathrm{B}$ areas.

All stations of type A (with the exception of Nørrebro) are located in a quite narrow interval of high-income areas (annual incomes of around DKK $190 \mathrm{~K}$ to $240 \mathrm{~K}$ ). The interpretation must be that these areas are more attractive. Since the income range is so narrow, there is hardly any relationship between income and fear of crime for this type ( $\mathrm{R} 2$ is close to zero). There are more type B stations in the dataset, and the income range is greater than in type A (from around DKK $170 \mathrm{~K}$ to $250 \mathrm{~K}$ ). Observations of type A fall almost completely within the variation of type $B$, hence there is no evidence for differences between these two types and fear of crime. Within type B, there is an increasing feeling of safety when income levels rise. When correcting for income level, Type $\mathrm{C}$ is characterized by a lower level of perceived safety compared to the other two neighborhood types. Type $\mathrm{C}$ is generally characterized by low-income areas, although in a wide range from DKK $120 \mathrm{~K}$ to $220 \mathrm{~K}$. One clear conclusion is that type $\mathrm{C}$ areas are less attractive and hence are populated by groups with lower incomes than the other two types. However, the fear of crime is higher in neighborhood type $\mathrm{C}$ than the low-income levels would indicate.

Table 1. The three types A, B and C, the number of stations in each category, their mean safety scores and standard deviations

\begin{tabular}{|l|l|l|r|r|}
\hline & & Count & Mean & Sd \\
\hline A & Income & 17 & 198.458 & 25.745 \\
& Safety & & 7,63 & 0,45 \\
\hline B & Income & 32 & 207.951 & 35.596 \\
& Safety & & 7,71 & 0,30 \\
\hline C & Income & 35 & 177.404 & 26.786 \\
& Safety & & 7,35 & 0,33 \\
\hline
\end{tabular}




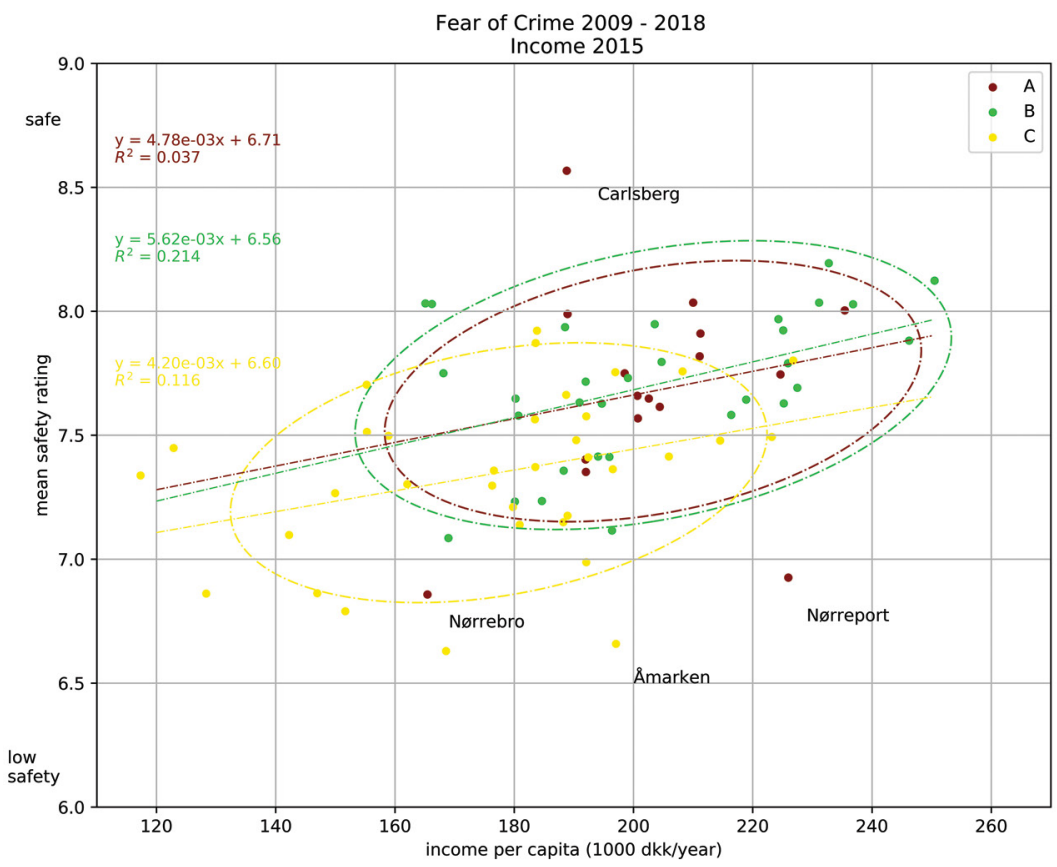

Figure 9. The relationships between fear of crime, income levels and station neighbourhood types

The linear distribution of types shows that the stations that are perceived as less safe are those with the lowest income levels (Figure 9). However, there are outliers in the graph: for example, Nørreport S-train station (type A, Dense Urban Area) is an old underground station with a high number of passengers, 111,005 a day in 2015 (metro, buses and regional trains not included). The platforms are narrow, the tunnels noisy, and passengers' fear aspects are associated with the characteristics of a congested station, so this outlier was expected. Carlsberg is a new station in a popular urban area. Åmarken station should have a low fear of crime according to its socioeconomic level, but the station area is type $\mathrm{C}$, and this could account for the higher level of fear. The station is close to a busy road, drawn away from urban activities with a large parking lot both in front of and behind the station. The station had only 2,500 passengers a day in 2015, which makes the area deserted outside peak hours. At Amarken station the effect of the built environment stands out from the effect of income. A micro-level analysis of Åmarken is required to be able to assess in greater detail the influence of local characteristics on passengers' fear of crime.

Lastly, in order to analyze the relationship between fear of crime, neighborhood type and average income levels simultaneously, a multiple regression analysis was carried out. The results show that income levels and feelings of safety are significantly positively correlated, as an increase in the average income of DKK 100,000 a year results in a 0.419 increase in the perceived safety level. At the same time, stations of type $\mathrm{C}$ have a 0.33 lower score for perceptions of safety than those of types $\mathrm{A}$ and $\mathrm{B}$ (Table 2). 
Table 2. A multiple regression table of station types, income and fear of crime. ${ }^{*} \mathrm{p}<0.05,{ }^{* *} \mathrm{p}<0.01$

\begin{tabular}{|ccc|}
\hline Variable & Coefficient & t-value \\
\hline Constant & $-6.908^{* *}$ & 24.54 \\
Type C & $-0.3335^{* *}$ & -3.93 \\
Income (1,000 DKK) & $0.00419^{* *}$ & 3.15 \\
\hline $\mathrm{N}$ & 79 & \\
$\mathrm{R} 2$ & 0.421 & \\
\hline
\end{tabular}

\section{Conclusion}

This article has investigated the correlations between neighborhood type, incomes and fear of crime at train stations in the Copenhagen metropolitan area. The results suggest that stations in Dense Urban Area, neighborhood type A, and Coherent Suburb, type B, have almost the same income patterns, but type B is perceived as the safest station neighborhood type. Type A, Dense Urban area, is regarded as relatively safe except for a few outliers. Stations in neighborhood type C, Fragmented Suburb, is regard as less safe. Residents in type $\mathrm{C}$ areas also have the lowest income and thus, according to social theories explaining fear of crime in relation to socio-economic parameters, are also more vulnerable. However, a significant research result is that when adjusting for income levels, passengers' fear of crime at stations follow the neighborhood typology. Thus, the data suggest that passengers' fear of crime at the stations is influenced by the urban form.

The correlation between the income level in the station neighborhood and fear of crime at the station gives weight to social theories of fear of crime, and the study also points out how tightly socioeconomic structures and the built environment are woven together. The strong relationship between the typologies of urban form and household income levels illustrate that those who are vulnerable are also exposed to an urban typology that may not support a positive experience of public space.

The relationship between fear of crime, neighborhood type and income in relation to passengers' experience of stations emphasizes the influence of urban form on our daily lives. However, it is important to underline that many other parameters than urban type or socioeconomic structure influence passengers' perceptions of safety, such as the media, hearsay about an area, actual crime and street-lighting. Therefore, the results of the analysis are an indication only and must be interpreted with caution.

Transit Oriented-Development (TOD) recognizes the influence of urban layout within an $800 \mathrm{~m}$ radius of the station on the use and integration of public transport (Thomas, Pojani, Lenferink, Bertolini, Stead, \& van der Krabben, 2018). A future study of the viewshed distance ${ }^{2}$ within the station area will reveal how the different station neighborhood types perform according to TOD design guidelines. Although the U.S. TOD strategies would need modification for purposes of Danish planning practice and culture, the guidelines could potentially support station neighborhood typology $\mathrm{C}$ in the S-train system.

The methods applied in this study can support planners and decision-makers in strategically developing train stations through an integrated approach that includes the design of the neighborhood and addresses the advantages and disadvantages of the types presented. The typomorphological methodol-

\footnotetext{
${ }^{2}$ The visual distance of approximately 100 meters from the station platform
} 
ogy can identify vulnerable urban layouts and provide strategies for the transformation of these areas, like densification, streetscape design and street networks and flows, to support the use of public transport, walking and bicycling to the station and enhance the perception of safety. This not only decreases car dependency and cuts down carbon emissions, it also creates better urban environments and social sustainability.

\section{Acknowledgements}

This article is the outcome of a three-year research project funded by the Danish Transport, Construction and Housing Authority and Innovation Fund Denmark: https://innovationsfonden.dk/en/aboutinnovation-fund-denmark\#accordion 1552 


\section{References}

AGIS. (2007). Annex D of the technical report prevention of crime by urban planning. In Planning, urban design, and management for crime prevention (A. S.- 2006-2007 (ed.). Brussels: CEN (European Committee of Standardization).

BRÅ. (2018). Utvecklingen i socialt utsatta områden i urban miljö 2006 - 2017. Retrieved from https:// doi.org/ISSN: 1100-6676

Byplanlaboratorium, D. (1993). Copenhagen regional plan: A summary of the preliminary proposal 1948-49. Copenhagen: Dansk Byplanlaboratorium.

Ceccato, V. (2013). Moving safely. Lanham, MD: Lexington Books.

Ceccato, V. (2015). Public space and the situational conditions of crime and fear. International Criminal Justice Review, 26(2), 69-79. https://doi.org/10.1177/1057567716639099

Cervero, R., Guerra, E., \& Al, S. (2017). Beyond mobility: Planning cities for people and places. Washington, DC: Island Press.

Cozens, P., \& Van der Linde, T. (2015). Perceptions of crime prevention through environmental design (CPTED) at Australian railway stations. Journal of Public Transportation, 18(4), 73-92.

CrimeConcern. (2004). People's perceptions of personal security and their concerns about crime on public transport: Research findings. Retrieved from http://www.dft.gov.uk/stellent/groups/dft_mobility/ documents/page/dft_mobility_028689.pdf

Cullen, G. (1961). The concise townscape. Oxford, UK: The Architectural Press.

Desyllas, J., Connoly, P., \& Hebbert, F. (2003). Modelling natural surveillance. Environment and Planning B: Planning and Design, 30(5), 643-655. https://doi.org/10.1017/S1743921307010253

Doran, B. J., \& Burgess, M. B. (2012). Putting fear of crime on the map. New York: Springer.

Egnsplankontoret. (1947). Skitseforslag til Egnsplan for Storkøbenhavn. Dansk Byplanlaboratorium. ISBN

Engström, C.-J. (1988). Svensk tätort. En kunskapssammanställing för planeringsändamål. Svenska Kommunförbundet.

Farrall, S., Bannister, J., Ditton, J., \& Gilchrist, E. (2007). Social psychology and the fear of crime. The British Journal of Criminology, 40(2000), 399-413.

Felson, M., Clarke, R. V, \& Webb, B. (1998). Opportunity makes the thief: Practical theory for crime prevention. In Policing and reducing crime unit: Police research series. https://doi.org/10.1186/21937680-1-3

Ferraro, K. F., \& Grange, R. L. (1987). The measurement of fear of crime. Sociological Inquiry, 57(1), 70-97. https://doi.org/10.1111/j.1475-682X.1987.tb01181.x

Forbrugerrådet Tænk. (2019). Passagerpulsen. Retrieved from https://passagerpulsen.taenk.dk/

Garofalo, J. (1981). The fear of crime: Causes and consequences. The Journal of Criminal Law and Criminology, 72(2), 839-857.

Gehl, J. (2010). Cities for people. Copenhagen: Danske Forlag

Goffman, E. (1972). Relations in public: Microstudies of the public order. London: Penguin Books.

Greenberg, S. W., Rohe, W. M., \& Williams, J. R. (1982). Safety in urban neighborhoods: A comparison of physical characteristics and informal territorial control in high and low crime neighborhoods. Population and Environment, 5(3), 141-165. https://doi.org/10.1007/BF01257054

Hanson, R. F., Smith, D. W., Kilpatrick, D. G., \& Freedy, J. R. (2000). Crime-related fears and demographic diversity in Los Angeles County after the 1992 civil disturbances. Journal of Community Psychology, 28(6), 607-623. https://doi.org/10.1002/1520-6629(200011)28:6<607::AIDJCOP5>3.0.CO;2-Y 
Hartoft-Nielsen, P. (1997). Lokalisering, transportmiddel og bystruktur. Byplan, 49(6), 247-260. https://doi.org/10.1081/E-EEE2-120046011

Harvey, C., Aultman-Hall, L., Hurley, S. E., \& Troy, A. (2015). Effects of skeletal streetscape design on perceived safety. Landscape and Urban Planning, 142, 18-28. https://doi.org/10.1016/j.landurbplan.2015.05.007

Jacobs, A., \& Appleyard, D. (1987). Toward an urban design manifesto. Journal of the American Planning Association, 53(1), 112-120. https://doi.org/10.1080/01944368708976642

Jacobs, A. B. (1993). Great streets: Monument Avenue, Richmond, Virginia. ACCESS Magazine, 1(3), $23-27$.

Jacobs, J. (1961). The death and life of great American cities. New York: Vintage Books.

Jeffery, C. R. (1971). Crime prevention through environmental design (2nd ed.). New York: Sage Publications.

Killias, M. (1990). Vulnerability: Toward a better understanding of a key variable in the genesis of fear of crime. Violence and Victims, 5(2), 127-140.

Knöll, M., Neuheuser, K., Cleff, T., \& Rudolph-Cleff, A. (2018). A tool to predict perceived urban stress in open public spaces. Environment and Planning B: Urban Analytics and City Science, 45(4), 797-813. https://doi.org/10.1177/0265813516686971

Knowles, R. D. (2012). Transit oriented development in Copenhagen, Denmark: From the finger plan to Ørestad. Journal of Transport Geography, 22, 251-261. https://doi.org/10.1016/j.jtrangeo.2012.01.009

Københavns Kommune. (2019). Københavns kommunes tryghedsundersøgelse 2019. Retrieved from www.kk.dk/artikel/tryghedsundersoegelsen

Liggett, R., Loukaitou-Sideris, A., \& Iseki, H. (2001). Bus stop-environment connection. Do characteristics of the built environment correlate with bus stop crime? Transportation Research Record: Journal of the Transportation Research Board, 1760(01), 20-27. https://doi.org/10.3141/1760-03

Loukaitou-Sideris, A. (2005). Is it safe to walk here? Design and policy responses to women's fear of victimization in public places. In Research on Women's Issues in Transportation-Volume 2: Technical papers, $102-112$.

Loukaitou-Sideris, A., Liggett, R., \& Iseki, H. (2002). The geography of transit crime. Documentation and evaluation of crime incidence on and around the Green Line stations in Los Angeles. Journal of Planning Education and Research, 22(2), 135-151. https://doi.org/10.1177/0739456X02238443

Moudon, A. V. (1992). The evolution of twentieth-century residential forms: An American case study. Urban Landscapes: An International Perspective, b, 173-176.

Moudon, A. V. (1994). Getting to know the built landscape: Typomorphology. In L. Franck \& K. A. Schneekloth (Ed.), Ordering space. Types in architecture and design (pp. 289-314). New York: Van Nostrand Reinhold.

Newman, O. (1972). Defensible space: Crime prevention through urban design. New York: Macmillan Publishing.

Nielsen, T. (2008). Gode intentioner og uregerlige byer (1st ed). Copenhagen: Arkitektskolens Forlag.

Painter, K. (1996). The influence of street lighting improvements on crime, fear and pedestrian street use, after dark. Landscape and Urban Planning, 35(2-3), 193-201. https://doi.org/10.1016/01692046(96)00311-8

Park, R. E., \& Burgess, E. W. (1925). The city (1984th ed.). Chicago: University of Chicago Press.

Peña-García, A., Hurtado, A., \& Aguilar-Luzón, M. C. (2015). Impact of public lighting on pedestrians' perception of safety and well-being. Safety Science, 78, 142-148. https://doi.org/10.1016/j. ssci.2015.04.009 
Rådberg, J., \& Friberg, A. (1996). Svenska stadstyper: Historik, exempel, klassificering (1st ed.). Stockholm: Tryck och Kopiering, KTH.

Rigspolitiet (Danish National Police). (2018a). Politiets Tryghedsundersogelse (the Police national survey of crime and perceived safety) (Issue December). Retrieved from https://politi.dk/-/media/mediefiler/dokumenter/landsdaekkende/statistikker/tryghedsundersoegelse/politiets-tryghedsundersgelse2018pdf.pdf?la=da\&hash=A2BBA100BB5A8BE9E8CABB71F0548C7DB0DF57B2

Rigspolitiet (Danish National Police). (2018b). Politiets Tryghedsundersøgelse Metoderapport (method report) (Issue December). Retrieved from https:/politi.dk/-/media/mediefiler/dokumenter/landsdaekkende/statistikker/tryghedsundersoegelse/politiets-tryghedsundersgelsemetoderapport-2018pdf. pdf?la=da\&hash=31A4DD456032E09546563816AB6992D400BB904A

Shaw, C. R., \& McKay, H. D. (1942). Juvenile delinquency and urban areas: A study of rates of delinquents in relation to differential characteristics of local communities in American cities. Chicago: University of Chicago Press.

Skogan, W. G., \& Maxfield, M. G. (1981). Coping with crime: Individual and nighborhood reactions. New York: SAGE Publication.

Spooner, D. D. (2007). Enclosure and walkability: An Italian street study. Environmental Design Research Association 38th Conference, 1926, 85-89.

Statistics Denmark. (2019). Retrieved from https://www.dst.dk/en

Stojanovski, T. (2018). How density, diversity, land use and neighborhood type influences bus mobility in the Swedish city of Karlstad: Mixing spatial analytic and typo-morphological approaches to assess the indirect effect of urban form on travel. Journal of Transport and Land Use, 11(1), 769-789. https://doi.org/10.5198/jtlu.2018.1089

Strandbygaard, S. K., Jensen, L. B., Grönlund, B., Nielsen, O. A., Jones, A. K. S., \& Flower, M. (2020). Understanding passengers' fear of crime at train stations through neighborhood types: A typological study of the Copenhagen metropolitan area. Journal of Urbanism (Forthcoming).

Taylor, R. B., \& Covington, J. (1993). Community structural change and fear of crime. Social Problems, 40(3), 374-397. https://doi.org/10.2307/3096886

Taylor, R. B., \& Hale, M. (1986). Testing alternative models of fear of crime. Journal of Criminal Law and Criminology, 77(1), 151-189. https://doi.org/10.1017/CBO9781107415324.004

Thomas, R., Pojani, D., Lenferink, S., Bertolini, L., Stead, D., \& van der Krabben, E. (2018). Is transitoriented development (TOD) an internationally transferable policy concept? Regional Studies, 52(9), 1201-1213. https://doi.org/10.1080/00343404.2018.1428740

Trafikstyrelsen. (2009). Bedre samspil mellem cyklen og den kollektive trafik. Idékatalog (Issue August). Retrieved from https://www.trafikstyrelsen.dk/ /media/Files/Databaser/Publikationer/TS cykelidekatalog august 2009.pdf

Uittenbogaard, A. C. (2014). Crime clusters and safety in underground stations (1sted.). Stockholm: KTH.

Vanderveen, G. (2006). Interpreting fear, crime, risk, and unsafety: Conceptualization and measurement. Boom Juridische Uitgevers.

Venerandi, A., Zanella, M., Romice, O., Dibble, J., \& Porta, S. (2017). Form and urban change — an urban morphometric study of five gentrified neighborhoods in London. Environment and Planning B: Urban Analytics and City Science, 44(6), 1056-1076. https://doi.org/10.1177/0265813516658031

Warr, M. (2000). Fear of crime in the United States: Avenues for research and policy. Criminal Justice, 4, 451-489.

Wilson, J. Q., \& Kelling, G. L. (1982). The police and neighborhood safety: Broken windows. The Atlantic Monthly, March, 29-38. https://doi.org/10.4135/9781412959193.n281 